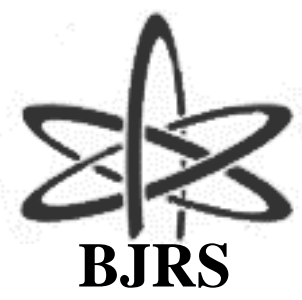

BRAZILIAN JOURNAL

$\mathrm{OF}$

RADIATION SCIENCES

08-03A (2020) 01-19

\title{
Knowledge management of research data: an initial analysis of Institute of Radiation Protection and Dosimetry
}

\author{
Razuck $^{\mathrm{a}}$ F.B. \\ ${ }^{a}$ Institute of Radiation Protection and Dosimetry, 2278-127, Rio de Janeiro, Brazil \\ fernandor@ird.gov.br
}

\begin{abstract}
It can be said that scientific community produces research data, as well as uses research data to validate its work. Thus, research data cease to be research products to become informational resources. In this context, digital data repositories play an extremely important role in the scientific research process, since they can be used to share, access, reuse and validate data. In this sense, the informational recognition of research data, in recent years, transformed the view that characterized them as simple by-products of research processes, to the point that researchers, academic institutions and research development agencies begin to understand that these data contribute as a source of informational resources for scientific research and science teaching. Based on this, the objective of this work is to make a preliminary survey of the type of research data generated at the Institute of Radiation Protection and Dosimetry (IRD). For this, an analysis was made of the papers published by the permanent professors of the Post-graduation Program in Radiation Protection and Dosimetry in the last year (2019). It was then generated a table relating the Concentration Areas versus some technical information, regarding the generation of research data. In this sense, the analysis of the data of the IRD consists of a initial stage to assist the creation of the Institute's Digital data repository, which aims to provide the research data in order to be used in other researches.
\end{abstract}

Keywords: knowledge management, research data, Institute of Radiation Protection and Dosimetry. 


\section{INTRODUCTION}

\subsection{The importance of Research Data}

The new scenario of scientific communication in the 21 st century, that occours through products (publications, digital repositories and service providers), processes (electronic publishing and communication) and their correspondences in the structure of scientific literature is composed of three types of sources: primary sources (online scientific publications); secondary (thematic and institutional repositories); and tertiary (service providers). Then, implementation and use of these three types of sources is urgent to promote scientific development [1].

Thus, it can be said that the informational recognition of research data in recent years has transformed the view that characterized them as simple by-products of the research processes, to the point that researchers, academic institutions and research promotion agencies begin to understand that these data can be a important source of information resources for scientific research and science teaching [2].

Although they are considered the foundation of scientific and technological knowledge, research data are not easy to structure, organize, describe and make available, so that they are understandable now and in the future [2].

The research data can then be classified as: observational (obtained through direct observations); computational (results from the execution of computational models or simulations); experimental (from controlled situations in laboratories) and identified as raw) or preliminary (derived directly from scientific instruments); derived (results from processing or combining raw data or other data); and referential or canonical (collections of data consolidated and archived generally in large data centers, e.g. genetic sequence, chemical structure, etc.) [2].

In this way, the research data can be understood as

\footnotetext{
...materials commonly registered and accepted in the scientific community as necessary to validate research results and include: facts and statistics collected for further reference or analysis, documents (text, Word), spreadsheets (Excel, etc.), laboratory notebooks field samples, diaries, questionnaires, transcripts, audio tapes, videotapes, photographs, films, protein or genetic sequences, test responses, slides, artifacts, samples, collection of digital objects acquired and generated during the process. search, database contents (video, audio, text, images), models, algorithms, scripts, log files, simulation software, methodologies and workflows, operational procedures, standards and protocols [3, p.2].
} 
This is because scientific research produces digital data as well as uses digital databases to validate your work. In this context, digital data repositories play an extremely important role in the scientific research process, since they can be used in data sharing, access, reuse and validation [2].

Finally, it can be said then that research data "is any and all types of records collected, observed, generated or used by scientific research, treated and accepted as necessary to validate the research results by the scientific community" [4].

\title{
1.2. Research Data, Data Science and Knowledge Management
}

With respect to digital databases, or digital repositories, these have been incorporated into the scientific information infrastructure and, in this way, data collections can be used, reused and shared. The importance of these data is due to the fact that

\begin{abstract}
Potentially, such data can enable researchers to formulate new types of inquiries, hypotheses, and use innovative analytical methods to study issues critical to science and society. In this direction, efficient data management is essential for the development of high quality research and excellence. Data management covers all aspects of data manipulation, organization, documentation and aggregation, and has a crucial role as a facilitator in data sharing processes, ensuring sustainability and long-term data accessibility. The actions and commitments promoted by the management, collectively, allow value data to be reused in other projects over time and space [2, p. 5].
\end{abstract}

Examples of data banks can be cited the World Data System (WDS), the International Council for Science (ICSU), the Research Data Alliance - RDA), an international organization for the development of infrastructure and promotion of activities aimed at reducing the barriers to exchange and sharing of data, STM Text and Data Mining for non-commercial scientific research, for data mining and the DataCite, which is an international non-profit organization that provides persistent identifiers (DOIs) for research data, Springer-Nature, the journal Nature, bi-directional Database Linking, the Elsevier Publishing House and the R3Data - Registry of Research Data Repositories, a search tool for data repositories [3].

Therefore, the management of the database becomes an essential process, not only in the preservation of the data, but as a secondary source for the generation of new scientific data.

Then, metadata (which is data that describes the attributes of a resource), can be used to associate data with objects that its users use to obtain complete benefits from knowledge of its characteristics or resources, transformed as raw data into knowledge. Therefore, a main use of 
metadata is documented and organizes the structured form of the organizations' data, with the aim of minimizing duplication of efforts and facilitating data maintenance [5].

And it is in this context of data preservation and their use as a research source that knowledge management is understood as a fundamental tool in this process.

In metadata management, for example, would be related to the stage of the organization within of the evolutionary hierarchy of knowledge management, so that organizations at the lower level of the hierarchy manage raw data, while more advanced organizations are able to manage their information resources at the Information, Knowledge, or Wisdom level (when actively monitoring their systems to ensure that their behavior is in accordance with the planned one, being able to evaluate the behavior of a system) [5].

In this sense, scientific production can be understood as an essential resource to promote the development of science, where the scientific journal, among other types of written communication, has become the main milestone in the constitution of the structure of scientific communication, as it emerged from genuine need for exchanges of scientific experience by scientists. In recent years, this production has evolved in the sense of allowing free access to scientific production, changing not only the process of acquiring scientific information, but also its production, dissemination and use. Thus, scientific journals began to share the stage of science with new protagonists, especially the institutional and thematic repositories, which are also present in the process that moves the productive cycle of science [2].

\section{MATERIALS AND METHODS}

Thus, this paper has as objective to make a previous survey of the type of data generated in the research carried out at the Postgraduate Program in Radiation Protection and Dosimetry (PPG) at Institute of Radiation Protection and Dosimetry (IRD).

For that, an analysis was made of the papers published by the permanent professors of the PPG in the last year (2019). It was then generated a table rationing the 4 (four) Concentration Areas (Medical Physics, Dosimetry, Metrology and Radioecology) versus some versus some technical 
information (such as methodology used, type/data of journal and if was deposited in some data bank or data repository), regarding the generation of research data.

The choice of papers is due to the fact that - as already discussed [3-5], that scientific journals are the main means of scientific communication - the Higher Education Personnel Coordination uses the Qualification of Intellectual Production (through Qualis) as one of the main criteria in the evaluation of graduate programs in Brazil [6-8].

\section{RESULTS AND DISCUSSION}

\subsection{The PPG of IRD}

With respect The PPG of IRD was created, respectively, in 2001 and 2012, at Master's and Ph. D levels. PPG is the only academic course in South America in Radiation Protection and Dosimetry. It is a typically Interdisciplinary area (according to the classification of Capes ${ }^{1}$ ) that includes, from the fundamentals of the phenomena that produce radiation, chemical methods of analysis, mathematical and / or computational simulation of processes and phenomena, the study of biological effects of radiation, socio-environmental problems involved and the basic principles of operation of the detection instruments [9].

About IRD, it is a research, development and teaching institution in the area of radioprotection, dosimetry and metrology of ionizing radiation. Linked to the National Nuclear Energy Commission (CNEN), it works in collaboration with universities, government agencies and industries to promote the safe use of ionizing radiation and nuclear technology. Its research, technical support and service activities have allowed it to develop new technologies and implement solutions so that the benefits of using ionizing radiation can safely reach an increasing number of Brazilians [10].

The PPG has four Concentration Areas:

1) Radiation Biophysics - studies on the interaction of radiation with biological systems, with research lines related to radiobiology, internal dosimetry of radionuclides in the human body and external dosimetry of photons and neutrons, and mathematical simulations, with development and adaptation of computer programs for theoretical dose calculations and detector simulation;

\footnotetext{
${ }^{1}$ The Coordination for the Improvement of Higher Education Personnel (CAPES) is the foundation responsible for the evaluation of Brazilian Postgraduate Stricto Sensu Programs.
} 
2) Medical Physics - studies on radiodiagnostic procedures (e.g. mammography, computed tomography, PET, SPECT, etc.) and development of therapeutic techniques (e.g., radioactive seed implantation, IMRT, radiosurgery, antiparticle therapy, etc;

3) Metrology - studies on the development of new measurement techniques, instrumentation and procedures, to meet the ever increasing demand for greater accuracy, greater reliability and faster measurements; and

4) Radioecology - studies on physical, chemical and biological processes that modulate environmental radioactivity, evaluation of the environmental impacts of activities related to the nuclear sector and related, as well as the sustainability of the technologies and remediation actions employed to recover the environmental quality.

The program is composed of 28 permanent professors. Of this total, the distribution of professors by concentration area is as follows: Biophysics of Radiation (BR, 7), Medical Physics (MP, 8), Metrology (ME, 6) and Radioecology (RE, 7). The PPG had scores 3 and 4 from Capes, for the Master and Doctorate, respectively.

\subsection{Research Data about Papers}

To obtain the research data regarding the Papers, an analysis based on the Lattes Curriculum of permanent professors and in the Sucupira Plataform Report (from Capes) about the IRD, for the year 2019, was performed.

The information considered to be explicit knowledge (to those found in the papers) - such as author (permanent professors were identified by letters), Journal, Paper Title, Keywords and Methodology are shown in Table 1.

Both keywords and Methodology were taken from the Abstract (in some cases the Objective appears together with the Methodology, since they are related and when the keywords were not found, they were abstracted from the Abstract).

Information considered to be tacit knowledge (that which is not explicitly found in the papers), such as Qualis (from Capes' large Interdisciplinary area, for Periodical Classifications of 2013- 
2016), Concentration Area of PPG, Index, Identificator, Impact Factor ${ }^{2}$, ISSN of the Journal, if the Journal is Open Access and the Publisher, are in Table 2.

Table 1: Explicit knowledge about the papers.

\begin{tabular}{|c|c|c|c|c|c|}
\hline $\mathbf{N}$. & Journal & Paper & Keywords & Methodology & Author \\
\hline 1 & $\begin{array}{l}\text { Anticancer } \\
\text { Research }\end{array}$ & $\begin{array}{l}\text { Anti-MUC1 aptamer } \\
\text { as carrier tool of the } \\
\text { potencial radiosensi- } \\
\text { tizer } 1,10 \text { phenan- } \\
\text { throline in MCF- } 7 \\
\text { breast cancer cells }\end{array}$ & $\begin{array}{l}1,10- \\
\text { phenanthroline; } \\
\text { Aptamer; MUC1; } \\
\text { breast cancer; } \\
\text { radiosensitizers }\end{array}$ & $\begin{array}{l}\text { Circular dichroism and } \\
\text { rhodamine labelling by } \\
\text { fluorescent microscopy } \\
\text { and flow cytometry }\end{array}$ & A \\
\hline 2 & $\begin{array}{l}\text { Applied } \\
\text { Radiation and } \\
\text { Isotopes }\end{array}$ & $\begin{array}{l}\text { A new approach for } \\
\text { the determination of } \\
{ }^{210} \mathrm{~Pb} \text { by Liquid Scin- } \\
\text { tillation counting }\end{array}$ & $\begin{array}{l}{ }^{210} \mathrm{~Pb} \text { determination, } \\
\text { Liquid scintillation } \\
\text { counting, In vitro } \\
\text { bioassay }\end{array}$ & $\begin{array}{l}\text { Two calibration methods: } \\
\text { one considering mostly } \\
\text { lead spectrum } \\
\text { contributions and other } \\
\text { that considers both lead } \\
\text { and bismuth } \\
\text { contributions. }\end{array}$ & B \\
\hline & $\begin{array}{l}\text { BMC Public } \\
\text { Health }\end{array}$ & $\begin{array}{l}\text { Temporal changes in } \\
\text { breast cancer } \\
\text { screening coverage } \\
\text { provided under the }\end{array}$ & $\begin{array}{l}\text { Breast cancer, } \\
\text { Screening } \\
\text { programs, } \\
\text { Mammography, }\end{array}$ & $\begin{array}{l}\text { This ecological study } \\
\text { analyzed data on breast } \\
\text { cancer screening within } \\
\text { the SUS for women aged }\end{array}$ & $\mathrm{C}$ \\
\hline
\end{tabular}

\footnotetext{
${ }^{2}$ The Impact Factor of a scientific journal is calculated only among the journals that make up the large collection of Web of Science. Therefore, citations from journals in the collection obtained from journals outside it or considered an Impact Factor for journals outside the WoS are not counted. The impact factor of scientific journals indexed to the Institute for Scientific Information has been published by the Journal of Citation Reports every year, beginning in 1972. The JCR gathers data from the Science Citation Index ( $\mathrm{SCl}$ ), Social Sciences Citation Index (SSCI) and Arts and Humanities Citation Index (AHCl), all published by the Institute for Scientific Information.
} 


\begin{tabular}{|c|c|c|c|c|c|}
\hline & & $\begin{array}{l}\text { Brazilian National } \\
\text { Health Service } \\
\text { between } 2008 \text { and } \\
2017\end{array}$ & $\begin{array}{l}\text { Healthcare } \\
\text { coverage, Brazilian } \\
\text { National Health } \\
\text { Service }\end{array}$ & $\begin{array}{l}50-69 \text { years. Coverage } \\
\text { was calculated from the } \\
\text { ratio between the number } \\
\text { of screening tests } \\
\text { conducted and the } \\
\text { expected number for the } \\
\text { target population. } \\
\text { Joinpoint regression } \\
\text { analysis was used to } \\
\text { calculate annual percent } \\
\text { changes (APC) in } \\
\text { coverage. }\end{array}$ & \\
\hline & $\begin{array}{l}\text { Brazilian } \\
\text { Journal of } \\
\text { Radiation } \\
\text { Sciences }\end{array}$ & $\begin{array}{l}\text { A fast method for the } \\
\text { determination of } \\
{ }^{210} \text { PB by LSC in liq- } \\
\text { uid samples }\end{array}$ & $\begin{array}{l}{ }^{210} \mathrm{~Pb} \text {, liquid } \\
\text { scintillation, in vitro } \\
\text { bioassay }\end{array}$ & $\begin{array}{l}\text { Suspension gel method } \\
\text { applied for faster } \\
\text { determination of }{ }^{210} \mathrm{~Pb} \text { by } \\
\text { liquid scintillation based } \\
\text { on simultaneous } \\
\text { radiochemical separation } \\
\text { of }{ }^{226} \mathrm{Ra} \text { and }{ }^{210} \mathrm{~Pb} \text {, by } \\
\text { direct measurement }\end{array}$ & B \\
\hline 5 & $\begin{array}{l}\text { Brazilian } \\
\text { Journal of } \\
\text { Radiation } \\
\text { Sciences }\end{array}$ & $\begin{array}{l}\text { Avaliação em micro- } \\
\text { cosmo da influência } \\
\text { de nanopartículas } \\
\text { (Hidroxiapatita e } \\
\text { PLGA) sobre o com- } \\
\text { portamento químico } \\
\text { de } \mathrm{Zn}, \mathrm{Cu} \text { e Mn em } \\
\text { sistema costeiro de- } \\
\text { gradado }\end{array}$ & $\begin{array}{l}\text { Nanoparticles; } \\
\text { polluted aquatic } \\
\text { environment; } \\
\text { microcosm essay }\end{array}$ & $\begin{array}{l}\text { Nanoparticles } \\
\text { (nanohydroxyapatite and } \\
\text { D, L-lactic-co-glycolic } \\
\text { acid - PLGA) with } \\
\text { promising use by nuclear } \\
\text { medicine were evaluated } \\
\text { by tests in microcosms, } \\
\text { reproducing the } \\
\text { conditions of the Canal } \\
\text { do Cunha (RJ) }\end{array}$ & $\mathrm{D}$ \\
\hline & $\begin{array}{l}\text { Brazilian } \\
\text { Journal of } \\
\text { Radiation } \\
\text { Sciences }\end{array}$ & $\begin{array}{l}\text { Bayesian estimation } \\
\text { of the relative devia- } \\
\text { tions between activi- } \\
\text { ties in the radionu- } \\
\text { clide standarization }\end{array}$ & $\begin{array}{l}\text { Radionuclide } \\
\text { metrology; } \\
\text { Radioactive source } \\
\text { preparation; } \\
\text { Bayesian statistic }\end{array}$ & $\begin{array}{l}\text { Bayesian estimates for } \\
\text { the relative deviation of } \\
\text { activities and their } \\
\text { uncertainty were obtained } \\
\text { in order to evaluate the } \\
\text { performance of the main } \\
\text { sources' preparation } \\
\text { method }\end{array}$ & $\mathrm{E}$ \\
\hline
\end{tabular}




\begin{tabular}{|c|c|c|c|c|c|}
\hline & $\begin{array}{l}\text { Brazilian } \\
\text { Journal of } \\
\text { Radiation } \\
\text { Sciences }\end{array}$ & $\begin{array}{l}\text { Calibração de um } \\
\text { sistema portátil para } \\
\text { bioanálise de amos- } \\
\text { tras de urina em situ- } \\
\text { ações de emergência }\end{array}$ & $\begin{array}{l}\text { Internal monitoring, } \\
\text { urine bioassay, } \\
\text { prompt response to } \\
\text { emergency }\end{array}$ & $\begin{array}{l}\text { System sensitivity was } \\
\text { evaluated based on the } \\
\text { minimum detectable } \\
\text { effective dose for }{ }^{103} \mathrm{Ru}, \\
{ }^{106} \mathrm{Ru},{ }^{134} \mathrm{Cs},{ }^{137} \mathrm{Cs} \mathrm{e}{ }^{60} \mathrm{Co} \\
\text { using AIDE software and } \\
\text { considering a scenario of } \\
\text { intake by inhalation }\end{array}$ & B \\
\hline 8 & $\begin{array}{l}\text { Brazilian } \\
\text { Journal of } \\
\text { Radiation } \\
\text { Sciences }\end{array}$ & $\begin{array}{l}\text { Mammography in } \\
\text { Brazil: regulatory } \\
\text { actions of acceptable } \\
\text { levels for glandular } \\
\text { dose }\end{array}$ & $\begin{array}{l}\text { Mammography, } \\
\text { glandular dose, } \\
\text { traceability, } \\
\text { national code of } \\
\text { practice }\end{array}$ & $\begin{array}{l}\text { Present and compare with } \\
\text { other studies, the results } \\
\text { of measurements of MGD } \\
\text { in a breast phantom. }\end{array}$ & E \\
\hline 9 & $\begin{array}{l}\text { Brazilian } \\
\text { Journal of } \\
\text { Radiation } \\
\text { Sciences }\end{array}$ & $\begin{array}{l}\text { Mapping the critical } \\
\text { intellectual capital of } \\
\text { IRD }\end{array}$ & $\begin{array}{l}\text { Knowledge } \\
\text { management, } \\
\text { nuclear, critical } \\
\text { knowledge }\end{array}$ & $\begin{array}{l}\text { Map the critical technical } \\
\text { areas at the Institute of } \\
\text { Radiation Protection and } \\
\text { Dosimetry (IRD), from } \\
\text { CNEN. }\end{array}$ & $\mathrm{E}$ \\
\hline & $\begin{array}{l}\text { Brazilian } \\
\text { Journal of } \\
\text { Radiation } \\
\text { Sciences }\end{array}$ & $\begin{array}{l}\text { Obtenção das equa- } \\
\text { ções de taxa de con- } \\
\text { tagem de pico des- } \\
\text { crevendo as coinci- } \\
\text { dências-soma de } \\
\text { Gama e Raios-X }\end{array}$ & $\begin{array}{l}\text { Coincidence } \\
\text { summing effect, } \\
\text { photon } \\
\text { spectrometry, } \\
\text { counting rate } \\
\text { equations, }{ }^{133} \mathrm{Ba}\end{array}$ & $\begin{array}{l}\text { Study the coincidence } \\
\text { summing effect in gamma } \\
\text { and X-rays spectrometry } \\
\text { of Ba-133, a method is } \\
\text { presented, using an Excel } \\
\text { spreadsheet, to apply the } \\
\text { theory developed by } \\
\text { Novković et al., based on } \\
\text { tracking all decay paths } \\
\text { of radioisotope with } \\
\text { complex decay scheme } \\
\text { and their outcomes, i.e., } \\
\text { deposited energies in the } \\
\text { detector and } \\
\text { corresponding detection } \\
\text { probabilities. }\end{array}$ & (1) \\
\hline & $\begin{array}{l}\text { Brazilian } \\
\text { Journal of } \\
\text { Radiation } \\
\text { Sciences }\end{array}$ & $\begin{array}{l}\text { Preclinical dosimetric } \\
\text { evaluation of Ixolaris } \\
\text { labeled with }{ }^{99} \mathrm{Mtc} \\
\text { and translational } \\
\text { model }\end{array}$ & $\begin{array}{l}\text { Preclinical } \\
\text { dosimetric, 99mTc- } \\
\text { Ixolaris, SPECT, } \\
\text { imaging dosimetry } \\
\text { method }\end{array}$ & $\begin{array}{l}\text { Aimed to determine the } \\
\text { biokinetic model for } \\
\text { Ixolaris labelled with } \\
99 \mathrm{mTc} \text { radiotracer in } \\
\text { mice by means of an } \\
\text { imaging dosimetry }\end{array}$ & $\mathrm{F}$ \\
\hline
\end{tabular}




\begin{tabular}{|c|c|c|c|c|}
\hline & & & $\begin{array}{l}\text { method to estimate the } \\
\text { absorbed and effective } \\
\text { doses resulting from the } \\
\text { diagnosis of melanoma } \\
\text { and metastases in } \\
\text { humans. }\end{array}$ & \\
\hline $12 \mid \begin{array}{l}\text { Brazilian } \\
\text { Journal of } \\
\text { Radiation } \\
\text { Sciences }\end{array}$ & $\begin{array}{l}\text { Quality control of } \\
\text { radiotherapy treat- } \\
\text { ment plans with elec- } \\
\text { trons }\end{array}$ & $\begin{array}{l}\text { Radiotherapy, Mon- } \\
\text { te Carlo dosimetry, } \\
\text { EGSnrc }\end{array}$ & $\begin{array}{l}\text { The quality of the } \\
\text { treatment planning } \\
\text { generated by EclipseÒ } \\
\text { commercial treatment } \\
\text { planning system for } \\
\text { electron beams of energy } \\
9 \text { and } 20 \mathrm{MeV} \text { was } \\
\text { verified and their } \\
\text { accuracy in the } \\
\text { calculation of dose } \\
\text { distributions for several } \\
\text { clinical situations was } \\
\text { evaluated. }\end{array}$ & $\mathrm{G}$ \\
\hline $13 \mid \begin{array}{l}\text { Brazilian } \\
\text { Journal of } \\
\text { Radiation } \\
\text { Sciences }\end{array}$ & $\begin{array}{l}\text { Radionuclide metrol- } \\
\text { ogy: traceability and } \\
\text { response to a radio- } \\
\text { logical accident }\end{array}$ & $\begin{array}{l}\text { Radionuclide } \\
\text { metrology, } \\
\text { radioactive standard } \\
\text { sources, } \\
\text { metrological } \\
\text { traceability, } \\
\text { response to a } \\
\text { radiological } \\
\text { accident; }{ }^{137} \mathrm{Cs}, \\
\text { Goiania. }\end{array}$ & $\begin{array}{l}\text { The paper presents the } \\
\text { demand for }{ }^{137} \text { Cs related } \\
\text { to the radioactive } \\
\text { accident in } \\
\text { Goiania/Brazil and the } \\
\text { significant results for the } \\
\text { main radionuclides } \\
\text { standardized by the } \\
\text { Radionuclide Metrology } \\
\text { Laboratory by } \\
\text { international key- } \\
\text { comparisons and national } \\
\text { comparisons to provide } \\
\text { metrological traceability. }\end{array}$ & $\mathrm{E}$ \\
\hline $14 \mid \begin{array}{l}\text { Brazilian } \\
\text { Journal of } \\
\text { Radiation } \\
\text { Sciences }\end{array}$ & $\begin{array}{l}\text { Sum-pak method } \\
\text { with two NaI(TL) } \\
\text { crystals: } 68(\mathrm{Ge}+\mathrm{Ga}) \\
\text { standarization }\end{array}$ & $\begin{array}{l}{ }^{68} \mathrm{Ge},{ }^{68} \mathrm{Ga} \text {, sum- } \\
\text { peak method, activi- } \\
\text { ty standardization, } \\
\text { anticoincidence } \\
\text { method }\end{array}$ & $\begin{array}{l}\text { The known germanium } \\
\text { volatility was tested using } \\
\text { three dried sources and } \\
\text { three liquid sources in the } \\
\text { sum-peak method } \\
\text { measurements }\end{array}$ & \\
\hline
\end{tabular}




\begin{tabular}{|c|c|c|c|c|}
\hline $15 \mid \begin{array}{l}\text { Brazilian } \\
\text { Journal of } \\
\text { Radiation } \\
\text { Sciences }\end{array}$ & $\begin{array}{l}\text { Uma revisão crítica } \\
\text { dos processos de } \\
\text { translação em radio- } \\
\text { terapia pré-clínica } \\
\text { associada às limita- } \\
\text { ções na dosimetria de } \\
\text { irradiadores biológi- } \\
\text { cos conformacionais }\end{array}$ & $\begin{array}{l}\text { Pre-clinical } \\
\text { radiotherapy, small } \\
\text { animal irradiation, } \\
\text { SARRP, kV small } \\
\text { field dosimetry }\end{array}$ & $\begin{array}{l}\text { Present, through a } \\
\text { literature review, the } \\
\text { characteristics of the } \\
\text { information reported in } \\
\text { the preclinical studies } \\
\text { involving ionizing } \\
\text { radiation and dose- } \\
\text { response relationships }\end{array}$ & $\mathrm{J}$ \\
\hline $16 \mid \begin{array}{l}\text { Geochimica } \\
\text { Brasiliensis }\end{array}$ & $\begin{array}{l}\text { Contribuição para o } \\
\text { mapeamento da radi- } \\
\text { oatividade natural no } \\
\text { Brasil - exposição } \\
\text { externa }\end{array}$ & $\begin{array}{l}\text { Natural background } \\
\text { radiation, public } \\
\text { exposure }\end{array}$ & $\begin{array}{l}\text { Make external dose } \\
\text { estimates to the Brazilian } \\
\text { population resulting from } \\
\text { this exposure. For the } \\
\text { calculation of effective } \\
\text { doses, the models used by } \\
\text { the United Nations } \\
\text { Scientific Committee } \\
\text { for the Effects of Atomic } \\
\text { Radiation (UNSCEAR) } \\
\text { were used }\end{array}$ & D \\
\hline $17 \begin{array}{l}\text { Geochimica } \\
\text { Brasiliensis }\end{array}$ & $\begin{array}{l}\text { Estudo preliminar } \\
\text { para a remediação de } \\
\text { áreas rurais após um } \\
\text { acidente nuclear ou } \\
\text { radiológico }\end{array}$ & $\begin{array}{l}\text { Remediation, } \\
\text { agricultural areas, } \\
\text { optimization, } \\
\text { nuclear accident. }\end{array}$ & $\begin{array}{l}\text { Definition of basic } \\
\text { criteria and use them for } \\
\text { prioritize radioecology } \\
\text { studies and soil mapping } \\
\text { in tropical areas, based on } \\
\text { soil characteristics and } \\
\text { yields farming in areas } \\
\text { surrounding Central } \\
\text { Nuclear Almirante } \\
\text { Alvaro Alberto in Angra } \\
\text { dos Reis }\end{array}$ & $\mathrm{D}$ \\
\hline 18 Haemophilia & $\begin{array}{l}\text { Outpatient treatment } \\
\text { for haemophilic ar- } \\
\text { thropathy with radio- } \\
\text { synovectomy: radia- } \\
\text { tion dose to family } \\
\text { members }\end{array}$ & $\begin{array}{l}\text { Family members; } \\
\text { haemophilic } \\
\text { arthropathy; } \\
\text { radiation dose; } \\
\text { radiosynovectomy }\end{array}$ & $\begin{array}{l}\text { This study analysed } 119 \\
\text { family members' safety } \\
\text { (16.7\% pregnant women). } \\
\text { The ambient dose } \\
\text { equivalent rate was } \\
\text { measured within four } \\
\text { distances. A survey was } \\
\text { carried analysing risk } \\
\text { groups and time spent } \\
\text { next to patients. }\end{array}$ & $\mathrm{K}$ \\
\hline
\end{tabular}




\begin{tabular}{|c|c|c|c|c|}
\hline $19 \begin{array}{l}\text { Health Policy } \\
\text { and Technology }\end{array}$ & $\begin{array}{l}\text { Patterns and trends in } \\
\text { outpatient diagnostic } \\
\text { imaging studies of } \\
\text { the Brazilian public } \\
\text { healthcare system, } \\
2002-2014\end{array}$ & $\begin{array}{l}\text { Diagnostic imaging, } \\
\text { Patterns, Trends, } \\
\text { Brazil }\end{array}$ & $\begin{array}{l}\text { Collected the annual } \\
\text { number of diagnostic } \\
\text { imaging procedures } \\
\text { among SUS outpatients } \\
\text { and the number of } \\
\text { diagnostic imaging } \\
\text { machines (in use in Brazil } \\
\text { and available to SUS) } \\
\text { from an online database } \\
\text { managed by SUS. }\end{array}$ & $\mathrm{G}$ \\
\hline $\begin{array}{l}20 \mid \begin{array}{l}\text { Journal of } \\
\text { Instumentation }\end{array}\end{array}$ & $\begin{array}{l}\text { Improved system } \\
\text { calibraton for } 131 \mathrm{I} \\
\text { spect image quatifica- } \\
\text { tion }\end{array}$ & $\begin{array}{l}\text { SPECT system } \\
\text { calibration, High } \\
\text { Count Density } \\
\text { (HCD), Low Count } \\
\text { Density (LCD) }\end{array}$ & $\begin{array}{l}\text { In the method presented, } \\
\text { the calibration factor (S0) } \\
\text { is determined by an } \\
\text { exponential fit of the } \\
\text { calibration curve, which } \\
\text { uses different threshold } \\
\text { levels for determination } \\
\text { of Volume of Interest. } \\
\text { The calibration factor was } \\
\text { calculated for images } \\
\text { with High Count Density } \\
\text { (HCD) and Low Count } \\
\text { Density (LCD), and } \\
\text { varying the source } \\
\text { position within the } \\
\text { phantom. To validate the } \\
\text { calibration method, the } \\
\text { calibration factors were } \\
\text { used for absolute } \\
\text { quantification of the total } \\
\text { reference activities. }\end{array}$ & $\mathrm{L}$ \\
\hline 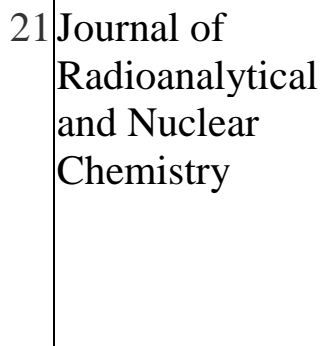 & $\begin{array}{l}\text { Production of spiked } \\
\text { vegetation samples } \\
\text { containing Y- } \\
\text { emitting radionu- } \\
\text { clides for proficiency } \\
\text { testing }\end{array}$ & $\begin{array}{l}\text { Spiked sample, } \\
\text { Vegetation, } \\
\text { Interlaboratory } \\
\text { comparison, } \\
\text { Radioactivity }\end{array}$ & $\begin{array}{l}\text { This work demonstrates } \\
\text { the feasibility of } \\
\text { producing vegetation } \\
\text { (grass) samples } \\
\text { containing }{ }^{60} \mathrm{Co},{ }^{65} \mathrm{Zn} \text {, } \\
{ }^{134} \mathrm{Cs} \text {, and }{ }^{137} \mathrm{Cs} \text { by the } \\
\text { spiked sample method. }\end{array}$ & $\mathrm{E}$ \\
\hline $22 \mid \begin{array}{l}\text { Journal of } \\
\text { Radiological }\end{array}$ & $\begin{array}{l}\text { Mean glandular dose } \\
\text { in digital mammog- }\end{array}$ & $\begin{array}{l}\text { Mean Glandular } \\
\text { Dose (MGD), }\end{array}$ & $\begin{array}{l}\text { This retrospective study } \\
\text { used data of } 2680\end{array}$ & $\mathrm{C}$ \\
\hline
\end{tabular}




\begin{tabular}{|c|c|c|c|c|}
\hline Protection & $\begin{array}{l}\text { raphy in women with } \\
\text { breast implants }\end{array}$ & $\begin{array}{l}\text { screening } \\
\text { mammography, } \\
\text { retrospective study }\end{array}$ & $\begin{array}{l}\text { mammographies of } 335 \\
\text { asymptomatic women } \\
\text { with mammary implants } \\
\text { examined in a digital } \\
\text { direct x-ray unit. }\end{array}$ & \\
\hline 23 Pharmaceutics & $\begin{array}{l}\text { Aptamers as delivery } \\
\text { gents of Sirna and } \\
\text { Chimeric formula- } \\
\text { tions for the treat- } \\
\text { ment of cancer }\end{array}$ & $\begin{array}{l}\text { siRNA; aptamers; } \\
\text { cancer; nanoparticle }\end{array}$ & Review & A \\
\hline \begin{tabular}{l|l}
24 & Progress in \\
Nuclear Energy
\end{tabular} & $\begin{array}{l}\text { Monte Carlo simula- } \\
\text { tion of novalis classic } \\
\text { 6-MV accelerator } \\
\text { using phase space } \\
\text { generation in } \\
\text { GATE/GEANT4 } \\
\text { Code }\end{array}$ & $\begin{array}{l}\text { GATE, Monte } \\
\text { Carlo, Phase space, } \\
\text { Novalis classic, } \\
\text { LINAC }\end{array}$ & $\begin{array}{l}\text { In this work, the } \\
\text { components of the } \\
\text { LINAC, excepting the } \\
\mu \text { MLC, were modeled } \\
\text { using the GATE/Geant } 4 \\
\text { code version } 7.1 .\end{array}$ & G \\
\hline \begin{tabular}{l|l}
25 & Radiation \\
Physics and \\
Chemistry
\end{tabular} & $\begin{array}{l}\text { Activity concentra- } \\
\text { tion and mapping of } \\
\text { radionuclides in Es- } \\
\text { pírito Santo state } \\
\text { soils, Brazil }\end{array}$ & $\begin{array}{l}\text { Activity } \\
\text { concentration, Soil } \\
\text { Map, Absorbed } \\
\text { dose, Effective dose }\end{array}$ & $\begin{array}{l}\text { Determine the activity } \\
\text { concentrations of }{ }^{40} \mathrm{~K}, \\
{ }^{226} \mathrm{Ra} \text {, and }{ }^{228} \mathrm{Ra} \text { in soils } \\
\text { of Brazilian state of } \\
\text { Espírito Santo, to produce } \\
\text { radionuclide } \\
\text { concentration distribution } \\
\text { maps to understand their } \\
\text { occurrence, and to } \\
\text { evaluate both the } \\
\text { absorbed and effective } \\
\text { doses. }\end{array}$ & $\mathrm{M}$ \\
\hline $\begin{array}{l}26 \\
\text { Radiation } \\
\text { Physics and } \\
\text { Chemistry }\end{array}$ & $\begin{array}{l}\text { Baseline, mapping } \\
\text { and dose estimation } \\
\text { of natural radioactivi- } \\
\text { ty in soils of the bra- } \\
\text { zilian state of Alago- } \\
\text { as }\end{array}$ & $\begin{array}{l}\text { Natural } \\
\text { radionuclides, Soil, } \\
\text { Dose assessment, } \\
\text { Radiological maps, } \\
\text { Potassium-40, } \\
\text { Radium }\end{array}$ & $\begin{array}{l}\text { This study aimed at } \\
\text { knowing the occurrence } \\
\text { of radionuclides }{ }^{40} \mathrm{~K}, \\
{ }^{226} \mathrm{Ra} \text { and }{ }^{228} \mathrm{Ra} \text { in soils in } \\
\text { the State of Alagoas, } \\
\text { located in the Northeast } \\
\text { region of Brazil. }\end{array}$ & M \\
\hline $\begin{array}{l}27 \\
\text { Radiation } \\
\text { Physics and } \\
\text { Chemistry }\end{array}$ & $\begin{array}{l}\text { Characterization and } \\
\text { applicability of low- } \\
\text { density materials for }\end{array}$ & $\begin{array}{l}{ }^{125} \text { I seeds, } \\
\text { Brachytherapy, } \\
\text { Sum-peak }\end{array}$ & $\begin{array}{l}\text { The analysis consists in } \\
\text { complete dissolution of } \\
\text { the seeds to obtain a }\end{array}$ & $\mathrm{H}$ \\
\hline
\end{tabular}




\begin{tabular}{|c|c|c|c|c|}
\hline & $\begin{array}{l}\text { making 3D physical } \\
\text { anthropomorphic } \\
\text { breast phantoms }\end{array}$ & $\begin{array}{l}\text { coincidence, } \\
\text { Ionization chamber }\end{array}$ & $\begin{array}{l}\text { homogeneous solution to } \\
\text { enable the primary } \\
\text { measurements based in } \\
\text { the coincidence sum-peak } \\
\text { measurements }\end{array}$ & \\
\hline $28 \mid \begin{array}{l}\text { Radiation Pro- } \\
\text { tection and En- } \\
\text { vironment }\end{array}$ & $\begin{array}{l}\text { International atomic } \\
\text { energy's analytical } \\
\text { laboratories for the } \\
\text { measurement of envi- } \\
\text { ronmental radioactiv- } \\
\text { ity network: experi- } \\
\text { ences ad perspectives } \\
\text { in the North and Lat- } \\
\text { in America Region }\end{array}$ & $\begin{array}{l}\text { Analytical } \\
\text { Laboratories for the } \\
\text { Measurement of } \\
\text { Environmental } \\
\text { Radioactivity, } \\
\text { capacity building, } \\
\text { collaboration, } \\
\text { environmental } \\
\text { radioactivity } \\
\text { measurements, } \\
\text { networking }\end{array}$ & $\begin{array}{l}\text { This qualitative study, } \\
\text { focusing on the NLAR } \\
\text { region, included two } \\
\text { main data sources: } \\
\text { experiences of } \\
\text { the ALMERA core } \\
\text { activities and } \\
\text { perspectives of the } \\
\text { coordination initiatives }\end{array}$ & $\mathrm{N}$ \\
\hline $29 \begin{array}{l}\text { Revista Brasi- } \\
\text { leira de Ensino } \\
\text { de Física }\end{array}$ & $\begin{array}{l}\text { A Simplified descrip- } \\
\text { tion of bodies float- } \\
\text { ing in the water }\end{array}$ & $\begin{array}{l}\text { Archimedes' } \\
\text { principle; } \\
\text { buoyancy; force } \\
\text { equilibrium; density }\end{array}$ & $\begin{array}{l}\text { Direct experimental } \\
\text { demonstrations }\end{array}$ & $\mathrm{O}$ \\
\hline $\begin{array}{l}\text { 30 Revista Brasi- } \\
\text { leira de Física } \\
\text { Médica }\end{array}$ & $\begin{array}{l}\text { Avaliação das expo- } \\
\text { sições ocupacionais } \\
\text { internas em Medicina } \\
\text { Nuclear - dificulda- } \\
\text { des e alternativas }\end{array}$ & $\begin{array}{l}\text { Medical physics; } \\
\text { nuclear medicine; } \\
\text { radiation protection }\end{array}$ & Review & B \\
\hline $\begin{array}{l}31 \\
\text { Revista de Ma- } \\
\text { temática da } \\
\text { Universidade } \\
\text { Federal de Ouro } \\
\text { Preto }\end{array}$ & $\begin{array}{l}\text { A Simple application } \\
\text { of the concept of } \\
\text { even and odd num- } \\
\text { bers }\end{array}$ & $\begin{array}{l}\text { Number, even and } \\
\text { odd numbers, } \\
\text { algorithm, } \\
\text { programming }\end{array}$ & Short note & $\mathrm{O}$ \\
\hline $\begin{array}{l}32 \text { The Physics } \\
\text { Educator }\end{array}$ & $\begin{array}{l}\text { On some aspects of } \\
\text { radiation protection } \\
\text { or high-school level } \\
\text { students }\end{array}$ & $\begin{array}{l}\text { Radiation } \\
\text { protection; radiation } \\
\text { shielding; linear } \\
\text { accelerators }\end{array}$ & Short note & $\mathrm{O}$ \\
\hline 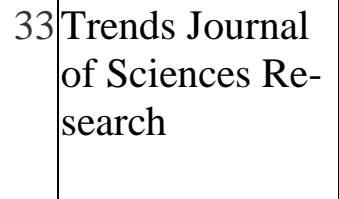 & $\begin{array}{l}\text { A tool for reporting } \\
\text { and evaluation of } \\
\text { incidents in external } \\
\text { beam radiation thera- }\end{array}$ & $\begin{array}{l}\text { Radiotherapy, Ra- } \\
\text { diation protection, } \\
\text { Incidents, Patient } \\
\text { protection, Quality }\end{array}$ & $\begin{array}{l}\text { A digital tool was } \\
\text { developed for recording } \\
\text { and evaluation of } \\
\text { incidents in external }\end{array}$ & $\mathrm{O}$ \\
\hline
\end{tabular}




\begin{tabular}{l|l|l|l|l}
\hline & py & management & beam radiation therapy. & \\
\hline
\end{tabular}

Table 2: Implicit knowledge about the Papers.

\begin{tabular}{|c|c|c|c|c|c|c|c|c|}
\hline N. & Qualis & $\begin{array}{c}\text { Concentration } \\
\text { Area }\end{array}$ & Index & Identificator & $\begin{array}{l}\text { Impact } \\
\text { Factor }\end{array}$ & ISSN & $\begin{array}{l}\text { Open } \\
\text { Acess }\end{array}$ & Editor \\
\hline 1 & B1 & $\mathrm{BR}$ & JCR & DOI & 1,935 & $\begin{array}{l}0250- \\
7005\end{array}$ & Yes & HighWire \\
\hline 2 & A2 & $\mathrm{BR}$ & JCR & DOI & 1.343 & $\begin{array}{l}0969- \\
8043\end{array}$ & Partial & Elsevier \\
\hline 3 & $\mathrm{~A} 2$ & MP & JCR & DOI & 2.567 & $\begin{array}{l}1471- \\
2458\end{array}$ & Yes & $\begin{array}{l}\text { Spinger } \\
\text { Nature }\end{array}$ \\
\hline 4 & A2 & $\mathrm{BR}$ & ISI & DOI & 1.036 & $\begin{array}{l}2319- \\
0612\end{array}$ & Yes & $\begin{array}{c}\text { Brazilian } \\
\text { Society of } \\
\text { Radiological } \\
\text { Protection }\end{array}$ \\
\hline 5 & $\mathrm{~A} 2$ & $\mathrm{RE}$ & ISI & DOI & 1.036 & $\begin{array}{l}2319- \\
0612\end{array}$ & Yes & $\begin{array}{c}\text { Brazilian } \\
\text { Society of } \\
\text { Radiological } \\
\text { Protection }\end{array}$ \\
\hline 6 & $\mathrm{~A} 2$ & $\mathrm{ME}$ & ISI & DOI & 1.036 & $\begin{array}{l}2319- \\
0612\end{array}$ & Yes & $\begin{array}{c}\text { Brazilian } \\
\text { Society of } \\
\text { Radiological } \\
\text { Protection }\end{array}$ \\
\hline 7 & A2 & $\mathrm{BR}$ & ISI & DOI & 1.036 & $\begin{array}{l}2319- \\
0612\end{array}$ & Yes & $\begin{array}{c}\text { Brazilian } \\
\text { Society of } \\
\text { Radiological } \\
\text { Protection }\end{array}$ \\
\hline 8 & A2 & $\mathrm{ME}$ & ISI & DOI & 1.036 & $\begin{array}{l}2319- \\
0612\end{array}$ & Yes & $\begin{array}{c}\text { Brazilian } \\
\text { Society of } \\
\text { Radiological } \\
\text { Protection } \\
\end{array}$ \\
\hline 9 & $\mathrm{~A} 2$ & $\mathrm{ME}$ & ISI & DOI & 1.036 & $\begin{array}{l}2319- \\
0612\end{array}$ & Yes & $\begin{array}{c}\text { Brazilian } \\
\text { Society of } \\
\text { Radiological } \\
\text { Protection }\end{array}$ \\
\hline 10 & $\mathrm{~A} 2$ & $\mathrm{ME}$ & ISI & DOI & 1.036 & $\begin{array}{l}2319- \\
0612\end{array}$ & Yes & $\begin{array}{c}\text { Brazilian } \\
\text { Society of } \\
\text { Radiological } \\
\text { Protection }\end{array}$ \\
\hline
\end{tabular}




\begin{tabular}{|c|c|c|c|c|c|c|c|c|}
\hline 11 & A2 & MP & ISI & DOI & 1.036 & $\begin{array}{c}2319- \\
0612\end{array}$ & Yes & $\begin{array}{c}\text { Brazilian } \\
\text { Society of } \\
\text { Radiological } \\
\text { Protection }\end{array}$ \\
\hline 12 & A2 & MP & ISI & DOI & 1.036 & $\begin{array}{c}2319- \\
0612\end{array}$ & Yes & $\begin{array}{c}\text { Brazilian } \\
\text { Society of } \\
\text { Radiological } \\
\text { Protection }\end{array}$ \\
\hline 13 & A2 & $\mathrm{ME}$ & ISI & DOI & 1.036 & $\begin{array}{c}2319- \\
0612\end{array}$ & Yes & $\begin{array}{c}\text { Brazilian } \\
\text { Society of } \\
\text { Radiological } \\
\text { Protection }\end{array}$ \\
\hline 14 & A2 & $\mathrm{ME}$ & ISI & DOI & 1.036 & $\begin{array}{c}2319- \\
0612\end{array}$ & Yes & $\begin{array}{c}\text { Brazilian } \\
\text { Society of } \\
\text { Radiological } \\
\text { Protection }\end{array}$ \\
\hline 15 & A2 & $\mathrm{ME}$ & ISI & DOI & 1.036 & $\begin{array}{c}2319- \\
0612\end{array}$ & Yes & $\begin{array}{c}\text { Brazilian } \\
\text { Society of } \\
\text { Radiological } \\
\text { Protection }\end{array}$ \\
\hline 16 & B4 & $\mathrm{RE}$ & OJS & DOI & $\mathrm{X}$ & $\begin{array}{c}0102- \\
9800\end{array}$ & Yes & $\begin{array}{c}\text { Federal } \\
\text { University of } \\
\text { Ouro Preto }\end{array}$ \\
\hline 17 & B4 & $\mathrm{RE}$ & OJS & DOI & $\mathrm{X}$ & $\begin{array}{c}0102- \\
9800\end{array}$ & Yes & $\begin{array}{c}\text { Federal } \\
\text { University of } \\
\text { Ouro Preto }\end{array}$ \\
\hline 18 & $\mathrm{X}$ & MP & JCR & DOI & 3.59 & $\begin{array}{c}1351- \\
8216\end{array}$ & & Wiley \\
\hline 19 & $\mathrm{X}$ & MP & JCR & DOI & 1.225 & $\begin{array}{c}2211- \\
8837\end{array}$ & Partial & ScieneDirect \\
\hline 20 & A2 & MP & JCR & DOI & 1.366 & $\begin{array}{l}1748- \\
0221\end{array}$ & Partial & IOPScience \\
\hline 21 & B2 & $\mathrm{ME}$ & JCR & DOI & 0.77 & $\begin{array}{c}0236- \\
5731\end{array}$ & Partial & Springer \\
\hline 22 & B1 & MP & JCR & DOI & 1.327 & $\begin{array}{c}0952- \\
4746\end{array}$ & Partial & IOPScience \\
\hline 23 & $\mathrm{X}$ & $\mathrm{BR}$ & JCR & DOI & 4.773 & $\begin{array}{c}1999- \\
4923\end{array}$ & Yes & MDPI \\
\hline 24 & B1 & $\mathrm{MP}$ & JCR & DOI & 1.569 & $\begin{array}{c}0149- \\
1970\end{array}$ & Partial & Elsevier \\
\hline 25 & B1 & RE & JCR & DOI & 1.984 & $\begin{array}{l}\text { 0969- } \\
806 \mathrm{X}\end{array}$ & Partial & Elsevier \\
\hline 26 & B1 & RE & JCR & DOI & 1.984 & 0969- & Partial & Elsevier \\
\hline
\end{tabular}




\begin{tabular}{|c|c|c|c|c|c|c|c|c|}
\hline & & & & & & $806 X$ & & \\
\hline 27 & B1 & $\mathrm{ME}$ & JCR & DOI & 1.984 & $\begin{array}{l}0969- \\
806 X\end{array}$ & Partial & Elsevier \\
\hline 28 & $\mathrm{X}$ & $\mathrm{RE}$ & DOAJ & DOI & $\mathrm{X}$ & $\begin{array}{l}0972- \\
0464\end{array}$ & Yes & $\begin{array}{c}\text { Indian } \\
\text { association } \\
\text { for Radiation } \\
\text { Protection } \\
\text { and } \\
\text { Dosimetry }\end{array}$ \\
\hline 29 & B1 & $\mathrm{MP}$ & JCR & DOI & 0.264 & $\begin{array}{l}1806- \\
1117\end{array}$ & Yes & $\begin{array}{c}\text { Brazilian } \\
\text { Physics } \\
\text { Society }\end{array}$ \\
\hline 30 & B5 & BR & $\begin{array}{l}\text { LOC } \\
\text { KSS }\end{array}$ & $\overline{\mathrm{DOI}}$ & $X$ & $\begin{array}{l}1984- \\
9001\end{array}$ & Yes & $\begin{array}{l}\text { Brazilian } \\
\text { Medical } \\
\text { Physics } \\
\text { Association }\end{array}$ \\
\hline 31 & $\mathrm{X}$ & $\mathrm{MP}$ & OJS & $X$ & $\mathrm{X}$ & $\begin{array}{l}2237- \\
8103\end{array}$ & Yes & $\begin{array}{c}\text { Federal } \\
\text { University of } \\
\text { Ouro Preto }\end{array}$ \\
\hline 32 & $\mathrm{X}$ & MP & $\begin{array}{l}\text { Por- } \\
\text { tico }\end{array}$ & DOI & $\mathrm{X}$ & $\begin{array}{l}2661- \\
3409\end{array}$ & Partial & $\begin{array}{c}\text { World } \\
\text { Scientific }\end{array}$ \\
\hline 33 & $\mathrm{X}$ & $\mathrm{MP}$ & $\begin{array}{l}\text { Coper } \\
\text { nicus }\end{array}$ & DOI & $\mathrm{X}$ & $\begin{array}{l}2377- \\
8091\end{array}$ & Yes & $\begin{array}{l}\text { ICI World } \\
\text { Journal }\end{array}$ \\
\hline
\end{tabular}

When analyzing the information contained in Tables 1 and 2, it can be inserted that:

- A total of 33 papers were published, with 15 different authors (permanent professors) in 19 different magazines;

- Regarding the authors, the number of papers was according to the following: A (2), B (4), C (2), D (3), E (8), F (1), G (3 ), H (2), I (1), J (1), K (1), L (1), M (2), N (1) and O (4);

- All areas of concentration have published at least one paper. The distribution of the number of papers by area, as well as the respective teachers is as follows: BR (4; A, B), ME (9; E, H, I, J), MP (14; C, F, G, K, L) and RE (6; D, L, M, N);

- It is observed that the relationship between the number of teachers and papers by area of concentration is well balanced;

- However, the PPG is composed of 29 permanent professors. If the total number of PPG professors is listed by the number of teachers who published in 2019, we would have the following relationship: Toral (29/15), BR (7/2), MP (8/5), ME (6/4) and RE (7/4) ; 
- With regard to Journals, most are indexed and have an impact factor; the editors are both national and international; the vast majority have DOI and are classified by Qualis;

- The most are free access (it is worth mentioning the issue of free access here. This is because, in Brazil, Capes signs an agreement with the largest publishers so that $R \& D$ institutions have free access. In this case, those considered "Partial" are those in which it is not possible to access the full paper if an IP without institutional access is used.

\section{CONCLUSION}

It is understood that the research database is of great relevance as an information resource, becoming an essential part of the research infrastructure on a global scale, making an important part of the research activity visible and open to society.

In this sense, this work aimed to make an initial exercise to understand the characteristics of the data generated by the IRD. It is intended, soon, to survey all professors permanent of the PPG at IRD.

Then, IRD data analysis consists of a relevant stage for the creation of the institute's Digital Data Repository, which has as its final objective to make available the generated data so that it can be used in other researches, considered a strategic step for the implementation of Knowledge Management in the IRD

To do this, however, a work must be done in partnership with the researchers, so that they identify and classify the types of data generated in their research, in order to assist the IRD in a possible process of creating a database of its own.

Another important issue in relation to the analysis of metadata is in relation to the tacit knowledge of the papers, since they can assist in the formulation of strategies for filling in Sucupira, an instrument used by Capes in the evaluation of Brazilian Postgraduate. Although this is not the initial objective of this article, the relevance of this information in this paper is clear.

\section{REFERENCES}


[1] WEITZEL, S. R. O papel dos repositórios institucionais e temáticos na estrutura da produção científica. Em Questão, v.12, n. 1, 2006.

[2] SAYÃO, L. F.; SALES, L. F. Guia de Gestão de Dados de Pesquisa para Bibliotecários e Pesquisadores, CNEN/IEN, Rio de Janeiro, 2015. Available at: <http://www.cnen.gov.br/images/CIN/PDFs/GUIA_DE_DADOS_DE_PESQUISA.pdf>. Last accessed: 10 Jan. 2020.

[3] DUDZIAK, E. Dados de Pesquisa agora devem ser armazenados e citados. 2016. Available at: <http://www.sibi.usp.br/?p=6189>. Last accessed: 10 Jan. 2020.

[4] SALES, L. F.; SAYÃO, L. F. Uma proposta de taxonomia para dados de pesquisa. Conhecimento em Ação, Rio de Janeiro, v. 4, n. 1, jan/jun. 2019.

[5] IKEMATU, R. S. Gestão de Metadados: Sua Evolução na Tecnologia da Informação. Revista de Ciência da Informação, v.2 n.6 dez, 2001.

[6] TRAJANO, M.A.B. ; CERETTA, C.A. ; RAZUCK, F.B. ; SCHEITINGER, M.R.C. A pósgraduação em zootecnia no Brasil: Uma análise conjuntural da situação atual e dinâmica da produção científica. Educação Agrícola Superior, v. 30, p. 90-99, 2015.

[7] TRAJANO, M.A.B. ; CERETTA, C.A. ; RAZUCK, F.B. ; SCHETINGER, M.R.C. . PósGraduação em Ciência do Solo no Brasil - Avanços e Perspectivas. Educação Agrícola Superior, v. 28, p. 21-29, 2013.

[8] TRAJANO, M. ; RAZUCK, F. B. ; CERETTA, C. A. ; SCHETINGER, M. R. C. Evolução da produção científica em Ciência do Solo no Brasil: um olhar sobre o Qualis. Geografia (Londrina), v. 22, p. 93-105, 2013.

[9] IRD. Ensino. Available at:< http://moodle.ird.gov.br/ensino/>. Last accessed: 15 Mar. 2020.

[10] IRD. O IRD. Available at:< http://www.ird.gov.br/>. Last accessed: 15 Mar. 2020. 